\title{
IMPACT OF EUROPEAN INTEGRATION PROCESSES ON THE NECESSITY OF LONG-TERM BUDGET PLANNING INTRODUCTION IN UKRAINE
}

\author{
Ganna Muzychenko' \\ South Ukrainian National Pedagogical University named after K.D. Ushynsky, Ukraine \\ Tetiana Koliada ${ }^{2}$ \\ University of State Fiscal Service of Ukraine, Ukraine \\ Iryna Churkina ${ }^{3}$ \\ Odesa Institute of Trade and Economics of Kyiv National University of Trade and Economics, Ukraine
}

\begin{abstract}
The Association Agreement between Ukraine and the European Union was ratified in September 2014. Ukraine has undertaken to implement and enforce EU standards, including in the financial sphere, which are regulated by international law. The purpose of the study is to determine the impact of European integration processes on the necessity of the long-term budget forecasting process introduction into the budget process of Ukraine and the revelation of special budgetary rules regulated this process in the EU. The methodology. The list of requirements (budget procedures and rules) for their introduction by law into the budget process of Ukraine was determined based on the generalization and systematization of normative legal acts that regulate the medium-term financial planning as the EU standard. The results showed that the long-term budget forecast developing procedure in the budget process will allow the government to timely identify the unfavourable trend in the state's fiscal policy and introduce preventive measures, determine the full scale of economy's and business' reaction to the reforms' introduction and new laws adoption, estimate fiscal space for fiscal policy implementation for coming years, take into consideration the budget forecast's indicators during the annual adoption of budget decisions. The study defines the difference between the budget forecast and the planned budget: the forecast is for five years and more, the plan is for one year only; forecast indicators are not mandatory for implementation, they are only guidelines, and planned indicators are mandatory for implementation; the budget forecast is approved by the order of the Cabinet of Ministers of Ukraine and annually specified, the planned budget (for the current budget year) is approved by the Verkhovna Rada of Ukraine by adopting the relevant law, amendments are an exception and also approved by law. The practical implementation. Governments of countries that systematically undertake long-term budget forecasts have developed effective measures to ensure the state sustainable development through the pension systems' restructuring or the creation of special funds for future needs. Publicity and availability of information about long-term sustainable development trends is a prerequisite for obtaining public support and confidence from the government's efforts to reduce the long-term budgetary tension.
\end{abstract}

Key words: long-term budget planning, budget process, special budget rules.

JEL Classification: E61, G28, H61, H68

\section{Introduction}

The transformation of the role of the budget as the most important instrument of the Government's targeted influence on the process of social production and the implementation of the long-term economic policy of the state in order to achieve sustainable development and increase the welfare of the population has necessitated the introduction of budget strategic planning and forecasting.

In the conditions of increasing the unfavourable tendencies in the socio-economic development of most

Corresponding author:

${ }^{1}$ Department of Political Sciences and Law, South Ukrainian National Pedagogical University named after K.D. Ushynsky.

${ }^{2}$ Department of Finance, University of State Fiscal Service of Ukraine.

${ }^{3}$ Department of Finance, Banking and Insurance, Odesa Institute of Trade and Economics of Kyiv National University of Trade and

Economics 
countries of the world (environmental problems, terrorist threats, aging of population, natural calamities, etc.), the demand for public services has increased, which has led to the growth of budget expenses and fiscal tightening (Koliada, 2016). Deceleration of economic growth forces governments to review the structure and volume of budget expenditures, to optimize budget expenses, to abandon spending on inefficient projects, because a significant increase of the part of the redistribution of GDP through the budget negatively impacts growth.

Among an up-to-day Ukrainian scientists who made a significant contribution to the study of the issues of the formation and development of budget forecasting and planning, the development of methods of perspective financial calculations, which are adequate to market transformations in the state we can point O. Cherniak, B. Hrabovetskyi, Hryshova I., V. Heiets, I. Kvasniuk, Yu. Kriuchkova, I. Lunina, M. Pashuta, and others. The scientific achievement of these scholars is to reveal peculiarities of scientific forecasting and planning, the study of methodological issues and the organization of economic forecasting and planning, the determination of the role and place of forecasting in the system of public administration.

While paying tribute to the scientific work of the scholars on this issue, it should be noted that in modern economic science and law, the problem of the coordination of the organizational and legal provision of the procedure for developing a budget forecast in Ukraine with the EU countries and justifying the necessity of its implementation to the budget process for making an intelligent decisions during the annual budget development and adoption.

\section{Background and necessity of elaboration of long-term budget plans}

The budget process consists of four stages. Planning that includes drafting, reviewing, and adoption of the budget is the most responsible stage, on which the effectiveness of budget execution depends, as well as the fullness of taking into account the current political needs (interests) of the government coalition and the probability of achieving the state's strategic priorities. Since the budget period lasts one year only, the shortterm time horizon does not allow the government to effectively manage budget resources and leads to a loss of control over the fiscal position of the state, which became especially vulnerable in the conditions of dangerous growth of the volume of public debt. In addition, this situation leads to ignoring previous and current decisions for developing a draft budget for the next budget period.

Most countries in the world, including Ukraine, have introduced medium-term budget planning for a threeyear time to overcome this negative practice in the budget process, which allows for a budget-balancing based on functional finances and increasing transparency in the management of state budget resources.

The medium-term budget can be a kind of protectant to avoid unreasonable future government expenditures that can negatively affect the rate of economic growth and the welfare of the country's population. At the same time, the indicators of budget revenues and expenditures for next years are only a forecast, which is periodically adjusted by the government in accordance with the trends of economic development and taking into account the various factors of influence that arise.

The EU has moved to developing an annual budget based on strategic long-term forecasting for recent years. The common approach to developing long-term budgeting is to include projected estimates of income and expenditure for several years ahead of the current year, but the practice of the formation of a budget strategy is significantly different in each country.

Among the main tasks to be fulfilled by long-term budget planning, we can determine the following (Baumann, 2015):

- Political: the establishment of government program objectives in the general perspective.

- Financial and economic: estimation of budgetary needs necessary for the realization of the defined goals and compliance with the annual balance between revenues and budget expenditures.

- General economic: reconciliation of probable expenses and revenues necessary for their coverage with general economic objectives and budgetary limits.

In order to stimulate research in the area of developing long-term forecasts, special provisions (rules of procedure) have been introduced into the fiscal legislation of the EU countries. The particular chapters on the quality of budgeting and sustainability of public finances, as well as the need for public announcements and holding debates on such issues in parliaments were mandatory included to the annual reports on the convergence and stability. Some countries have provided an additional legislative requirement for governments. In particular, in Belgium since 2001, it was determined that the government should provide an annual memorandum on population aging; Sweden introduced a mandatory report on expected longterm public finance implications as a result of the implementation of the proposed government proposals.

\section{Legislative environment for the organization of budget planning in EU countries}

All countries participating in the Eurozone must observe fiscal parameters for the general government sector prescribed by the Maastricht Treaty and Stability and Development Pact (SDP) (Resolution, 1997). In particular, the upper limits for the annual budget deficit at the level of $3 \%$ of GDP and total debt to $60 \%$ of GDP. According to the SDP, the state should implement the 
principle of a balanced budget and develop annual programs to ensure stability and economic growth that contribute to the fulfilment of identified targets.

The critical state of public finance has forced many governments, including European ones, to introduce new fiscal rules, the so-called "next generation" to combat the financial crisis, which take into account the phases of the economic cycle, that is, ups and downs of economic development. Budget rules are long-term restrictions for major budget supplies in the form of quantitative limits of deficits, debt, expenses or revenues. According to the IMF's Department of Finance, at the end of 2012, more than 75 countries applied such rules at the country or supranational level, compared with only 5 in 1990 (Budina, 2012). According to experts, new fiscal rules are able to manage the holding excessive increases in government spending and, thus, to ensure budget balance and debt sustainability of the state. Additionally, some countries are implementing other institutional mechanisms, such as fiscal councils for monitoring fiscal policies and focusing public attention on its trends and outcomes.

By ratifying the Association Agreement between Ukraine and the European Union in September 2014 (Law of Ukraine, 2014) Ukraine has committed itself to implementing and enforcing EU standards, including in the financial sector, which are regulated by international law. In particular, it is about mediumterm financial planning as the EU standard, where Article 9 of the Framework Budget Directive (2011) stipulates that the EU Member States are establishing valid, effective medium-term fiscal frameworks that provide for at least three years of financial planning in order to ensure long-term perspectives in national financial planning (Council Directive, 2011). At the same time, medium-term financial planning covers a five-year time horizon, where the first year is the current budget year, the second year is the year for which the budget is being drafted, and the third, fourth, and fifth years are a budget forecast.

The Framework Budget Directive (Article 9) also defines a list of procedures relating to the medium-term budget framework. They are:

- establishment of comprehensive and transparent multiyear budgetary targets for the national deficit, level of indebtedness and other general financial indicators;

- giving an estimation and forecasts based on the assumption of maintaining policy intact for each article of revenues and expenditures in the state budget with detailed data on certain budget sectors (functions of the state) at the central (state) level and social insurance for the current budget year and beyond;

- preparation of a description of medium-term planned measures that have an impact on national finances, decoding the main revenue and expenditure items and explaining how they should correspond with the medium-term budgetary targets as compared to the estimation and forecasts based on the assumption of maintaining policy intact;

- assessing the question of how planned political measures with their direct long-lasting impacts to national finances will probably affect the long-term stability of public finances;

- using realistic indicators of macroeconomic and budgetary forecasts for the prospective estimations development, on which medium-term fiscal frameworks are based (Council Directive, 2011).

Thus, the Framework Budget Directive's rules and procedures implementation aim at the introduction of long-term perspective financial planning corresponded with the medium-term budgetary objectives of the state into the budget process.

Another regulatory document defining medium-term financial planning as an EU standard is the Stability and Growth Pact (1997). This document regulates the technical conditions of control in the field of fiscal policy and the "oversize deficit procedure" - the requirements for limiting budget deficits (Resolution, 1997). The 2009 economic and financial crisis has exacerbated the pressure on public finances of EU member states, in particular, in terms of rising public debt, and prompted a number of innovations to the Stability and Growth Pact (2011) aimed at strengthening economic and financial supervision.

If the Stability and Growth Pact (1997) stipulates only limits on the maximum budget deficit - no more than $3 \%$ of GDP and public debt - no higher than $60 \%$ of GDP (in accordance with the Maastricht Treaty of 1992), then starting in 2013, when the "Fiscal Pact" came into force after ratification by all EU member states, new restrictions were introduced in addition, such as:

- medium-term budgetary objective (annual growth of government expenditures should not exceed their growth rates in the medium-term) (Regulation, 1175); - development of recommendations for the mediumterm budget forecast within the debt procedure (Regulation, 1177);

- rule $1 / 20$ to reduce the level of government debt (in case of the public debt size exceeding up of $60 \%$ of GDP, the annual 5\% reduction of this excess is mandatory) (Regulation, 1173);

- structural deficit of the state budget is no higher than $0.5 \%$ of GDP (for countries with a public debt below $60 \%$ of GDP - no higher than $1 \%$ of GDP) (Directive, 2011).

The Pact set out the requirements for fiscal policy formulation and medium-term financial planning, which include a procedure for these "European budgetary rules" mandatory implementation in the national legislation of the countries ratified this document (25 states). It is anticipated that these innovations will contribute to ensuring economic stability in the country, restoring the confidence of economic agents 
to government actions and prevent future crises in the euro area and the EU.

Taking into account the course of Ukraine's integration into the European space and in order to effectively manage public debt, the issue of introducing special "second-generation" budget rules that exist in most EU countries and providing for special rules combining the size limitations for the budget deficit and public debt is relevant. In particular, it is a question of using as a supplementary indicator of budgetary security of the state a new indicator - the percentage of the structural deficit (surplus) of the public debt to GDP, that is, a deficit that would be possible under conditions of full or high employment of potential productive and labour resources and at the existing level of government expenditures and tax rates (Koliada, 2015).

As the current legislation of Ukraine already contains norms imposing budget limits defined in the previous version of the Stability and Growth Pact (1997), it is logical to assume that amendments to the Budget Code of Ukraine will be introduced in the near future regarding the introduction of new budget limits, in particular, on reducing the level of government debt and the volume of structural budget deficits due to the existence of a threat to the national security and the need to adapt domestic legislation to European requirements.

\section{Prospects and benefits of long-term budget planning introduction in Ukraine}

The difference between the budget forecast (strategy) and the planned budget is that the forecast is for five years and more, the plan is for one year only; forecast indicators are not mandatory for implementation, they are only guidelines, and planned indicators are mandatory for the implementation; the budget forecast is approved by the Cabinet of Ministers of Ukraine order and annually specified, the planned budget (for the current budget year) is approved by the Verkhovna Rada of Ukraine by adopting the relevant law, the amendments are an exception and also approved by law. The long-term budgetary planning introduction in Ukraine or extension of the medium-term budget planning horizon to a five-year period should be based on the relevant Constitution norms, as it is foreseen in Germany, or the Budget Code of Ukraine. Such a provision should regulate the obligation to introduce a procedure for a five-year budget forecasting in the budget process, where the volume (in relative indexes to GDP) and the composition of probable expenditures and budget revenues should be determined in accordance with the scenarios of the country's economic development, if necessary, to determine the sources for the budget deficit funding.

The authority to make a budget forecast should rely on the Ministry of Finance of Ukraine, which is approved by the Cabinet of Ministers of Ukraine and submitted to the Verkhovna Rada of Ukraine for consideration. At the same time, the annual correction of the budget forecast and its prolongation takes place in accordance with the trends and dynamics of the country's economic development.

Based on previous scientists' research, it is possible to identify elements of the budget strategic planning system, which consist of three large blocks: forecasting, program-targeted planning and strategic control. The first block includes the development of scientifically sound ideas about the budget strategy's priorities and objectives, taking into account tasks of socio-economic development and national security of the country, as well as indicators of budgetary rules. The second block is the formation of a complex of measures identifying the sources and the amount of their financing, aimed at achieving program objectives and priorities. The third block is monitoring the budget strategy introduction, control over managerial decisions implementation, which have been made during the budget strategic planning process, as well as achieving strategic goals, taking into account the efficiency of the use of public funds (Dementev, 2012).

The governments of the countries that systematically undertake long-term budget forecasts have developed effective measures to ensure the state sustainable development through the pension systems' restructuring or the creation of special funds for future needs. Publicity and availability of information about longterm sustainable development trends is a prerequisite for obtaining public support and confidence from the government's efforts to reduce the long-term budgetary tension.

\section{Conclusion}

The introduction of long-term budget forecast developing procedure as a component of the economic strategic planning system to the budget process, as well as its consolidation and regulation by law are actively used in most countries of the world as an instrument of state regulation of the economy. Existence of the State's strategic plan for development helped a number of countries to change the socio-economic situation in a qualitative way during the 20th century that, in particular, in the USA during the 1930s and 1940s, Germany, France, and Italy in the 1950s and 1960s, South Korea in the 1970s, 1980s, China in the 1980s and 1990s. Strategic budget planning is currently used in EU countries, the United States, Canada, the UK, Japan, the Russian Federation, and other states. Eliminating the multidirectional priorities of state development, balancing budget revenues and expenditures, creating an effective mechanism for the concentration of resources for solving medium and long-term tasks are allowed by the budget strategy (forecast) which is codified by law. 
Prospects for further research in this direction are to prove the necessity of legislative consolidation of the long-term budget forecast developing procedure in the budget process. It will allow the government to timely identify the unfavourable trend in the state's fiscal policy and introduce preventive measures, determine the full scale of economy's and business' reaction to the reforms' introduction and new laws adoption, estimate fiscal space for fiscal policy implementation for coming years, take into consideration the budget forecast's indicators during the annual adoption of budget decisions.

\section{References:}

Baumann, E. (2014). Planning and forming of realistic and transparent budget. Finances of Ukraine, Vol. 9, p. 7-20. Budina, N., Shekhter, A. (2012). Watching of application of tax-budgetary rules. Finances and development, Vol. 9, p. 57-62.

Council Directive 2011/85/EU on requirements for budgetary frameworks of the Member States. Official Journal, Vol. L 306, p. 41-47.

Dementev, V. (2012). The strategic planning is a mortgage of successful development. Budget, Vol. 7, p. 17-21. Retrieved from: http://bujet.ru/article/193728.php

Directive 2011/85/EU: On requirements for budgetary frameworks of the Member States.

Hryshova, I., Zamlynskyi, V., Shestakovska, T. (2017). Implementing Cluster Forms into National Education Development Strategy. Science and Education, Vol. 5, p. 56-61.

Hryshova, I., Nikolyuk, E., Shestakovska, T. (2017). Conceptualization of the Organizational management Mechanism of the Development of the National Education System in the Context of its Quality. Science and Education, Vol. 10, p. 118-125.

Koliada. T. (2016). Forming of budgetary strategy of Ukraine: theory, methodology, practice - Irpin: University of State Fiscal Service of Ukraine, 396 p.

Koliada, T. (2015). Debt management in the context of public finances stabilization in Ukraine. Economic magazine - XXI, Vol. 7-8 (1), p. 82-85.

Law of Ukraine 1678-VII Association Agreement between the European Union and the European Atomic Energy Community and their member states, of the one part, and Ukraine, of the other part (Kyiv, 16 September 2014) Retrieved from: http://zakon4.rada.gov.ua/laws/show/984_011

Resolution of the European Council on the Stability and Growth Pact (Amsterdam, 17 June 1997). Official Journal, Vol. 40, 236 p.

Regulation 1175/2011 amending Regulation 1466/97: On the strengthening of the surveillance of budgetary positions and the surveillance and coordination of economic policies.

Regulation 1177/2011 amending Regulation 1467/97: On speeding up and clarifying the implementation of the excessive deficit procedure.

Regulation 1173/2011: On the effective enforcement of budgetary surveillance in the euro area. 